\title{
ANTIGENIC PROFILE OF RAT VESICULO-PROSTATE COMPLEX
}

\author{
G. W. BARNES* AND S. EL-MOFTY $\dagger$ \\ Department of Pathology, State University of New York, Buffalo \\ (Received 3rd May 1968, revised 17th February 1969)
}

\begin{abstract}
Summary. Serological studies of male accessory sex tissues, employing rabbit antiserum to rat vesiculo-prostate complex, have indicated a high degree of specificity for the accessory glands system. By gel diffusion methods, the accessory glands, i.e. seminal vesicle, coagulating gland, ventral and dorsolateral prostates, and Cowper's and preputial glands, have been found to contain common antigen(s), although some of the glands were shown to have individually specific antigens as well. A slowly diffusing antigen was highly characteristic of the vesiculoprostate complex and was found consistently in seminal vesicle, coagulating gland and dorsolateral prostate, as well as bulbo-urethral gland and vas deferens. Testis, uterus and mammary gland, and nongenital tissues gave negative reactions with the tissue-specific antisera. A study of other species of vesiculo-prostate (human, monkey, guineapig, rabbit and mouse) showed that only the mouse contained crossreacting antigen(s).

By immunofluorescence, it was confirmed that rat accessory glands contained common antigen(s) and that the mouse contained crossreacting antigen(s). The specific nature of the homologous reaction was confirmed by tanned cell haemagglutination.

It is implicit in these findings that the highly tissue-specific, speciesrestricted antigens which characterize the accessory sex glands may be used to classify them and study their growth, function and evolution.
\end{abstract}

\section{INTRODUCTION}

The immunological approach to the study of organs and tissues is based on the assumption that knowledge at the antigenic level leads to an understanding of the nature and function of these structures and their cellular constituents (Dumonde, 1966). Although functional studies have been carried out on male accessory glands for a number of years, it has only recently become clear that these tissues and their secretions can be characterized by tissue-specific antigens.

The earlier antigenic studies on spermatozoa and semen (Landsteiner, 1899; Metchnikoff, 1900; Farnum, 1901; Hektoen \& Manly, 1923; Ross, 1946) failed to provoke investigative interest in seminal plasma as a possible secretory

* Present address: Department of Urology, School of Medicine, University of Washington, Seattle, Washington.

$\dagger$ Present address: School of Dentistry, University of Cairo, Egypt, U.A.R. 
product of the accessory glands. Although the cellular features of semen had intrigued immunologists from the very beginning and led to many useful studies of spermatozoa, interest in the immuno-reproductive importance of the accessory glands had to await the recognition that seminal proteins are specific in nature, originate largely in the accessory glands, and must play some role in fertilization (Weil, Kotsevalov \& Wilson, 1956; Rao, Sadri \& Sheth, 1959; Weil, 1967).

Flocks, Urich, Patel \& Opitz (1960) reported that the human prostate gland contained antigens peculiar to the prostate, antigens found in other tissues, and antigens recognized as serum proteins. These observations were corroborated independently by our antigenic studies of human and dog prostatic fluids (Barnes, Soanes, Mamrod, Gonder \& Shulman, 1963a, b; Barnes, Shulman, Gonder \& Soanes, 1965) and these studies formed a basis for other immunological or immunochemical experiments on the male accessory glands system, including some concerned with autosensitization (Shulman, Yantorno, Barnes, Gonder, Soanes \& Witebsky, 1965), immunochemical characterization (Soanes, Shulman, Mamrod, Barnes \& Gonder, 1963) and biological function (Barnes, 1966; Barnes \& El-Mofty, 1967, 1968).

The experiments described in this report represent an effort to broaden the approach to accessory gland specificity in order to increase the fund of knowledge essential to the immunological study of the physiology (Dufour, Gagnon, Tremblay, Proulx \& Lemieux, 1965; Barnes \& El-Mofty, 1968) and evolution of these glands. The specific objective was to outline the antigenic properties of rat vesiculo-prostatic tissues by a combination of immunological and serological procedures.

\section{MATERIALS AND METHODS}

\section{Preparation of antigens}

Adult, male Sprague-Dawley rats of the Holtzman strain were anaesthetized with diethyl ether and the vesiculo-prostate complex, consisting of seminal vesicles, coagulating glands and dorsolateral and ventral prostates, was removed and trimmed of fat and connective tissue. Several complexes were weighed individually or together, care being exercised in either case to avoid loss of the fluid contained in the glands. They were then minced and ground in saline ( $1 \mathrm{ml} / \mathrm{g}$ of tissue) in an ice-water-cooled Sorvall tissue grinder (Omni-Mixer). A portion of the homogenate was set aside and the remainder was centrifuged in the cold, decanted and the supernatant set aside. The sediment was extracted overnight by adding a further volume of saline ( $2 \mathrm{ml} / \mathrm{g}$ of tissue) and allowing the suspension to stand in the cold for about $18 \mathrm{hr}$. The suspension was centrifuged and this supernatant was pooled with the first.

Individual glands were carefully separated, weighed and used for the preparation of extracts in a manner similar to that used for preparing extract with the whole complex. Following excision and weight determinations, nongenital organs and tissues were extracted in the manner previously described. Pooled serum was prepared from bleedings of normal adult animals of both sexes. Before use, the pooled samples were clarified by centrifuging in the cold, lyophilized and stored in the cold. 
Preparation of antisera

Four New Zealand albino rabbits were used in the preparation of antisera. Soluble antigens were incorporated into Freund complete adjuvant and injected intracutaneously and subcutaneously into sites on the back, shoulders and thighs of the animals. Each animal received an initial injection of about $20 \mathrm{mg}$ of protein, followed by three or four injections (one/week) of a similar amount incorporated into the incomplete adjuvant. The animals were allowed to rest for 3 or 4 weeks following the first course of immunization and given two or three monthly boosters thereafter until they were killed. Bleedings were usually begun during the 4th week of injection and continued on a weekly basis until the animals were killed.

\section{Procedures}

Two-dimensional direct immunodiffusion in agar gel was carried out in accordance with the procedure of Ouchterlony (1948) in plastic Petri dishes (Falcon Plastics, Culver City, California).

Immunofluorescent staining was carried out in accordance with Coons' direct staining method (Coons \& Kaplan, 1950; Marshall, Eveland \& Smith, 1958). Cryostat sections were prepared from quick-frozen vesiculo-prostatic tissues and fixed in acetone or alcohol for $10 \mathrm{~min}$. They were stained directly with fluorescein isothiocyanate conjugate of antiserum globulin for 1 to $2 \mathrm{hr}$, followed by a 10-min rinse in buffered saline. Unspecific staining was reduced by passing the conjugate through a G-25 Sephadex column and absorbing with 1 vol of washed, packed rat or human liver sediment for $1 \mathrm{hr}$ at $37^{\circ} \mathrm{C}$. The sections were covered with buffered glycerol and cover slips. The stained specimens were examined with a Zeiss fluorescent microscope equipped with an Osram HBO-200 lamp and Leica 35-mm camera. The film used was Anscochrome T-100.

Tanned cell haemagglutination (Boyden, 1951), employing fresh tanned rabbit cells as particulate carriers, and complement fixation (100\% end-point method) were performed as described previously (Barnes et al., 1965). For tanning the rabbit cells, tannic acid was diluted $1: 30,000$ in saline. This was followed by the usual procedures for coating with soluble protein antigen $(0.1 \%)$. For complement fixation, initial antigen dilutions consisted of $1 \%$ soluble protein and both antiserum and antigen titrations were made.

Antisera were absorbed at appropriate times with lyophilized preparations of serum. One hundred $\mathrm{mg}$ of the rat serum powder, as determined by preliminary gel diffusion tests, was dissolved in $1 \mathrm{ml}$ of the antiserum and the mixture was placed in a water bath at $37^{\circ} \mathrm{C}$ for $30 \mathrm{~min}$. This was followed by refrigeration at $5^{\circ} \mathrm{C}$ overnight. The precipitate was removed by centrifugation and the supernatant serum used in this form or absorbed further with other antigens according to need. Protein determinations were carried out by the biuret method described by Gornall, Bardawill \& David (1949).

\section{RESULTS}

Analysis of reproductive organs by gel diffusion and immunofuorescence

Rabbit anti-complex serum contained antibodies which precipitated in 
agar gel with both rat serum and prostate (Pl. 1, Fig. 1). When the antibodies reacting with blood serum antigens were removed by absorption with serum powder, the homologous reaction still produced two prominent bands. One of these, which together with one or two minor lines was designated band-group A, formed nearer to the antigen reservoir by slow diffusion (Pl. 1, Fig. 1). The second, less prominent but more rapidly diffusing band was also accompanied by one or two minor bands and was labelled band-group B (Pl. 1, Fig. 2).

Each of the glands comprising the complex contributed antigens to the tissuespecific pattern formed by the complex with anti-complex serum. The two major bands were produced by dorsolateral prostate (Pl. 1, Fig. 3a, well 4) and coagulating gland (Pl. 1, Figs. $3 \mathrm{a}$ and $3 \mathrm{~b}$, well $\mathrm{Ag}$ ), seminal vesicle (Pl. 1, Figs. $4 \mathrm{a}$ and $4 \mathrm{~b}$, well $\mathrm{Ag}$ ) and by ventral prostate. However, ventral prostate usually produced several rapidly advancing, distinctly organ-specific bands and only a faint line near the antigen reservoir identified with major antigen(s), B, of the complex (Pl. 2, Fig. 5).

Some of the peripheral accessory reproductive organs tested by gel diffusion, Cowper's gland (Pl. 2, Fig. 6, well 2), preputial gland (Pl. 2, Fig. 6, well 3) and vas deferens (not shown) gave, in that order, cross-reactions of decreasing diversity and intensity with specific anti-complex serum. Slowly diffusing antigen (band-group A) was demonstrated in Cowper's gland, vas deferens and also, though not invariably, in the preputial gland as well. Epididymis gave a single faint band in only one out of several tests performed. Reproductive tissues that produced no gel diffusion reaction with the antiserum were testis, mammary gland and uterus.

Direct, immunofluorescent staining of dorsal, lateral and ventral prostates, coagulating gland and seminal vesicle showed that the epithelial cells and the luminal secretions gave specific reactions, while the stroma and blood vessels either stained faintly or not at all (Pl. 2, Figs. 7 to 10; Pl. 3, Fig. 11). Generally, the cytoplasm of the epithelial cells showed a granular staining reaction while the nuclei were unstained. The dorsal prostate contained stained granules and islets of cells in the lumen (Pl. 2, Fig. 7), the lateral prostate displayed stained granules and partially stained masses of secretion in its lumen (Pl. 2, Fig. 8) and the ventral prostate showed heavy cytoplasmic staining and an abundance of stained luminal granules. In contrast to the dorsal and lateral prostates, the ventral prostate also exhibited increased staining of the basement membrane and connective tissue elements (Pl. 2, Fig. 9). Extensive epithelial and secretory staining was seen in both coagulating gland and seminal vesicle (Pl. 2, Fig. 10; Pl. 3, Fig. 11). The lack of connective tissue staining was rather distinct in the former.

\section{Analysis of complex by $C^{\prime}$ fixation and tanned cell haemagglutination}

A consistent distinction between complex extract and blood serum could not be made with unabsorbed antiserum by the $\mathrm{C}^{\prime}$-fixation test or, as shown in Table 1 , by tanned cell haemagglutination indicating a heavy admixture of serum proteins in the tissue extract.

However, when anti-complex sera were absorbed with rat serum powder or 
unwashed complex sediment (Table 1), the tissue and serum tanned-cell haemagglutination reactions were clearly distinguished from one another.

\section{Analysis of non-reproductive organs by gel diffusion}

Anti-complex serum produced reactions with several organs and tissues which were routinely abolished by absorption of the antiserum with rat blood serum. All of the non-genital tissues were tested in this manner, using antisera prepared from different bleedings, and found to be devoid of accessory gland antigens.

\section{Analysis of species by gel diffusion and immunofuorescence}

Of the several species of complexes tested with anti-rat prostate serum, only the mouse gave a cross-reaction. As shown in Pl. 3, Fig. 12, this species produced a single line that coalesced with one or both of the two lines formed by slowly diffusing band-group A rat complex. The spur formation by antigens of the rat complex in this region of fusion indicated that the mouse antigens were at least partially identical to one or more of the rat complex antigens.

\section{TABLE 1}

TANNED-CELL HAEMAGGLUTINATION REACTION OF RABBIT ANTI-RAT COMPLEX* SERUM WITH RAT COMPLEX AND NORMAL RAT SERUM

\begin{tabular}{l|c|c|c}
\hline \multirow{2}{*}{ Antiserum } & Absorbent & \multicolumn{2}{|c}{ Titre $\dagger$} \\
\cline { 2 - 3 } & & Complex & Normal rat serum \\
\hline \multirow{2}{*}{ R2279 } & Complex sediment & 320 & 320 \\
& Normal rat serum & 320 & 160 \\
& Complex sediment & 5120 & 10240 \\
& Normal rat serum & 5120 & 160 \\
\hline
\end{tabular}

* Seminal vesicles, coagulating gland and ventral and dorsolateral prostates.

$\uparrow$ Reciprocal of dilution.

Application of a fluorescent conjugate of the antiserum to mouse complex tissues resulted in specific staining of the seminal vesicle (Pl. 3, Figs. 13 and 14), dorsolateral prostate (Pl. 3, Fig. 15) and coagulating gland (Pl. 3, Fig. 16). Seminal vesicle showed solid acinar staining (Pl. 3, Fig. 14) and luminal staining (Pl. 3, Fig. 15). Specific staining of cords of epithelial cells was seen in the dorsolateral prostate, and to a lesser degree in the surrounding connective tissue. Secretion in the coagulating gland appeared brightly stained, while the epithelial cells contained only a few stained granules (PI. 3, Fig. 16).

\section{DISCUSSION}

Studies of individual rat accessory glands have shown that they have strong histological and histochemical similarities (Engle, 1926; Korenchevsky \& Dennison, 1935), and one might infer that antigenic similarities must also 
exist. The results of the present study emphasize this point; the major glands of the rat complex contained a common precipitating antigen, though not in equal amounts. The nature of this antigen could not be determined from the results, since the same study had shown that anti-complex serum contained a multiplicity of precipitin-type tissue antibodies. Hence, the specific epithelial fluorescence observed in the different tissues might have been produced by several different specific antibodies contained in the labelled antiserum. In this connection, it is of interest that the luminal secretion in the lateral prostate, and to some extent in the dorsal prostate, was only partially stained with anticomplex serum. One might speculate that luminal antigen undergoes denaturation for some reason or that the luminal secretion consists of an admixture of both antigenic and non-antigenic substances. In other studies, the idea of common antigenicity among these glands is also supported by agar immunoelectrophoresis; an antigen has been demonstrated in the major glands which forms a heavy arc at the point of application in the presence of anti-complex serum, its absence from vas deferens and the epididymis suggesting the complex itself as the initial source.

According to our gel diffusion experiments, certain antigenic differences co-exist with the similarities between these glands. The ventral prostate and seminal vesicle differed from each other and from the dorsolateral prostate and coagulating gland. In other studies, antiserum prepared with ventral prostate only has not revealed as great a distinction between this gland and the others as has been demonstrated in the present study with antiserum to the whole complex indicating, perhaps, the potency of even small quantities of the major antigens in the ventral prostate. On the other hand, the epididymis was shown to contain specific antigens with anti-epididymis serum while in the present study such antigens have not been demonstrated with anti-complex serum. Thus, antigenic differences between glands in the male reproductive system as shown in this study may be considered indicative of histo-anatomical as well as functional differences, but resolution of the question must await a complete analysis with antisera to individual glands or their purified antigens.

Rabbit vesiculo-prostatic tissues have been found to be highly specific through autosensitization studies (Shulman et al., 1965; Yantorno, Soanes, Gonder \& Shulman, 1967). The lack of cross-reactions of non-genital tissues with anti-complex serum observed in this study by gel diffusion leads to the conclusion that the rat accessory glands system also contains substances which endow it with unusually specific characteristics. The high degree of specificity of rat accessory glands' proteins permitted them to be readily detected among other proteins in body fluids by serological procedures (Barnes, 1966, 1967).

The observation that rabbit anti-rat complex serum cross-reacts with mouse complex, but not with that of rabbit or guinea-pig, may be considered taxonomically consistent. Even when a tissue contains proteins which show extensive species cross-reactivity, as in the case of the lens, the antigenic juxtaposition of the rat and mouse is apparent, while the guinea-pig and rabbit seem to form a separate group (Manski, Halbert \& Auerbach, 1964). A marked similarity between rat and mouse prostatic responses to castration and androgen administration has been noted (Mann, 1964). 


\section{ACKNOWLEDGMENTS}

We wish to thank Mrs Dorothea Newman for valuable technical assistance, Luther Joseph for reliable support in animal care and experimentation, Mrs Miriam Barnes for animal surgery and technical assistance, Mrs Helen Sanderson (Oral Pathology, School of Dentistry) for preparing histological slides, and Manfred Gygli and Robert Linsmair for preparing photographs.

Also, we wish to pay special thanks to Professor Floyd R. Skelton and Professor George W. Greene for their support and encouragement during the course of this study, and Professor Solon A. Ellison for his criticism of the manuscript.

This work was supported by USPHS GRS Grant 50-8759 and USPHS Grant HE 0695 and includes parts of a thesis written by S.E.L. for the Ph.D. degree, State University of New York, Buffalo, 1967.

\section{REFERENGES}

Barnes, G. W. (1966) Observations on prostate antigens in blood and urine. (Abstract). Fedn Proc. Fedn Am. Socs exp. Biol. 25, 355.

Barnes, G. W. (1967) Antigens in mammalian cells: discussion. In: Immunity, Cancer and Chemotherapy, p. 308. Ed. E. Mihich. Academic Press, New York.

Barnes, G. W. \& EL-MofTY, S. (1967) Antigenic analysis of rat vesiculo-prostate complex. (Abstract). Fedn Proc. Fedn Am. Socs exp. Biol. 26, 754.

BARnes, G. W. \& EL-MofTY, S. (1968) Immunofluorescent and immunodiffusion study of male rat reproductive glands. (Abstract). Sixth Int. Congr. Anim. Reprod. and A. I., Paris.

Barnes, G. W., Shulman, S., Gonder, M. J. \& Soanes, W. A. (1965) Further studies of the immunological properties of human prostatic fluid. 7. Lab. clin. Med. 66, 741.

Barnes, G. W., Soanes, W. A., Mamrod, L., Gonder, M. J. \& Shulman, S. (1963a) Immunologic studies of prostatic fluid. (Abstract). Fedn Proc. Fedn Am. Socs exp. Biol. 22, 498.

Barnes, G. W., Soanes, W. A., Mamrod, L., Gonder, M. J. \& Shulman, S. (1963b) Immunologic properties of human prostatic fluid. 7. Lab. clin. Med. 61, 578.

BOYDEN, S. V. (1951) Adsorption of proteins on erythrocytes treated with tannic acid and subsequent hemagglutination by antiprotein sera. F. exp. Med. 93, 107.

Coons, A. H. \& Kaplan, M. H. (1950) Localization of antigen in tissue cells. II. Improvements in a method of the detection of antigen by means of fluorescent antibody. F. $\exp$. Med. 91, 1.

Dufour, D., Gagnon, P.-M., Tremblay, A., Proulx, J. \& Lemieux, S. (1965) Caractérisation des relations antigèniques et enzymatiques entre la prostate et l'urine humaine. Laval méd. 36, 643.

Dumonde, D. C. (1966) Tissue-specific antigens. In: Advances in Immunology, Vol. 5, p. 245. Eds. F. J. Dixon, Jr and J. H. Humphre. Academic Press, New York.

ENGLE, E. T. (1926) The copulating plug and the accessory genital glands of mammals. F. Mammal. $7,119$.

Farnum, C. G. (1901) The biological test for semen. F. Am. med. Ass. 37, 1721.

Flocks, R. H., Urich, V. C., Patel, C. A. \& OptTz, J. M. (1960) Studies on the antigenic properties of prostatic tissue. F. Urol. 84, 134.

Gornall, A. G., Bardawill, C. J. \& David, M. M. (1949) Determination of serum proteins by means of the biuret reaction. 7. biol. Chem. 177, 751.

Hektoen, L. \& Manly, L. S. (1923) Specific precipitin reaction of semen. F. infect. Dis. 32, 167.

Korenchevsky, V. \& Dennison, M. (1935) Histological changes in the organs of rats injected with oestrone alone or simultaneously with oestrone and testicular hormone. F. Path. Bact. 41, 323.

Landsteiner, K. (1899) Zur Kenntnes der Spezifisch auf Blutkorperchen Wirkenden Sera. Zentbl. Bakt. Parasitkde, 25, 546.

ManN, T. (1964) The biochemistry of semen and of the male reproductive tract, p. 47. John Wiley and Sons, New York.

Manski, W., Halbert, S. P. \& Auerbach, T. D. (1964) Immunochemical analysis of the phylogeny of lens proteins. In: Taxonomic Biochemistry and Serology, p. 545. Ed. C. A. Leone. The Ronald Press, New York.

Marshall, J. D., Eveland, W. C. \& Smith, C. W. (1958) Superiority of fluorescein isothiocyanate (Riggs) for fluorescent antibody technic with a modification of its application. Proc. Soc. exp. Biol. Med. 98, 898. 
Metchnikoff, E. (1900) Recherches sur l'influence de l'organisme sur les toxines. Annls Inst. Pasteur, Paris, 14, 1 .

Ouchterlony, O. (1948) In-vitro method for testing the toxin-producing capacity of diphtheria bacteria. Acta path. microbiol. scand. 25, 186.

RAO, S. S., SADRI, K. K. \& SHETH, A. R. (1959) Immunological studies with human semen and cervical mucus. In: Proc. 6th Int. Conf. plann. Parent., p. 313. International Planned Parenthood Federation, London.

Ross, V. (1946) Precipitin-reactions of human seminal plasma. F. Immun. 52, 87.

Shulman, S., Yantorno, G., Barnes, G. W., Gonder, M. J., Soanes, W. A. \& Witebsky, E. (1965) Studies on autosensitization to prostatic tissue and related tissues. Ann. N.Y. Acad. Sci. 124, 279.

Soanes, W. A., Shulman, S., Mamrod, L., Barnes, G. W. \& Gonder, M. J. (1963) Electrophoretic analysis of prostatic fluid. Classification according to agar gel electrophoresis. Investve Urol. 1, 269.

Weir, A. J. (1967) Antigens of the seminal plasma. F. Reprod. Fert., Suppl. 2, 25.

Weil, A. J., Kotsevalov, O. \& Wrlson, L. (1956) Antigens of human seminal plasma. Proc. Soc. exp. Biol. Med. 92, 606.

Yantorno, C., Soanes, W. A., Gonder, M. J. \& Shulman, S. (1967) Studies in cryo-immunology. I. The production of antibodies to urogenital tissue in consequence of freezing treatment. Immunology, 12, 395.

\section{EXPLANATION OF PLATES}

\section{PLATE I}

Fig. 1. Reaction of unabsorbed rabbit anti-rat complex serum with complex extract and normal rat serum. Well Ag: complex; Wells 1 and 4: antiserum; Wells 2, 3, 5 and 6: normal rat serum. $\mathrm{A}=$ slow diffusing antigen(s); $\mathrm{B}=$ fast diffusing antigen(s).

FIG. 2. Reaction of anti-complex serum (absorbed with lyophilized normal rat serum) with complex extract and normal rat serum. Well As: antiserum; Wells 1 and $4:$ complex; Wells $2,3,5$ and $6:$ normal rat serum. $\mathrm{A}=$ slow diffusing antigen(s); $\mathrm{B}=$ fast diffusing antigen(s).

FIG. 3a. Reaction of anti-complex serum (absorbed with lyophilized normal rat serum) with extracts of isolated accessory glands. Well $\mathrm{Ag}$ : coagulating gland; Well 4: dorsolateral prostate; Well 5 : antiserum. $\mathrm{A}=$ slow diffusing antigen $(\mathrm{s}) ; \mathrm{B}=$ fast diffusing antigen(s).

Fig. 3b. As Fig. 3a. Well Ag: coagulating gland; Well 1: complex; Well 2: antiserum. $\mathrm{A}=$ slow diffusing antigen(s); $\mathrm{B}=$ fast diffusing antigen(s).

FIG. 4a. Reaction of anti-complex serum (absorbed with lyophilized normal rat serum) with extract of isolated accessory glands. Well Ag: seminal vesicle; Well 1: complex; Well 2: antiserum.

Fig. 4b. As Fig. 4a. Well Ag: seminal vesicle; Well 4: dorsolateral prostate; Well 5: antiserum. $\mathrm{A}=$ slow diffusing antigen $(\mathrm{s}) ; \mathrm{B}=$ fast diffusing antigen $(\mathrm{s})$.

\section{PLATE 2}

FIG. 5. Reaction of anti-complex serum (absorbed with lyophilized normal rat serum) with extracts of isolated accessory glands. Well $\mathrm{Ag}$ : complex; Well 1: ventral prostate; Well 2: antiserum.

Fig. 6. Reaction of anti-complex serum (absorbed with lyophilized normal rat serum) (Well As) with extracts of Cowper's (Well 2) and preputial (Well 3) glands. Wells 1 and 4: complex. $\mathbf{A}=$ slow diffusing antigen $(s) ; B=$ fast diffusing antigen(s).

Figs. 7 to 10. Reaction of fluorescein-labelled anti-rat complex serum (absorbed with lyophilized normal rat serum and washed sediment of human liver) with individual complex glands. Fig. 7: Dorsal prostate, $\times 400$. Fig. 8: Lateral prostate, $\times 250$. Fig. 9: Ventral prostate, $\times 400$. Fig. 10: Coagulating gland, $\times 400$. Ct $=$ connective tissue, $\mathrm{Ep}=$ epithelial cells, Lu = lumen, Se = secretion.

\section{PLATE 3}

FIG. 11. Reaction of fluorescein-labelled anti-rat complex serum (absorbed with lyophilized normal rat serum and washed sediment of human liver) with individual complex glands. Seminal vesicle. Note the intermixture of epithelium (Ep) and secretion (Se). $\times 400$.

FIG. 12. Reaction of anti-rat complex serum (As) (absorbed with lyophilized normal rat serum) with complex extract of rat in agar (Wells 1 and 4), mouse (Well 2), guinea-pig (Well 3), man (Well 5) and monkey (Well 6). 
$1 ' 1.111 ;$

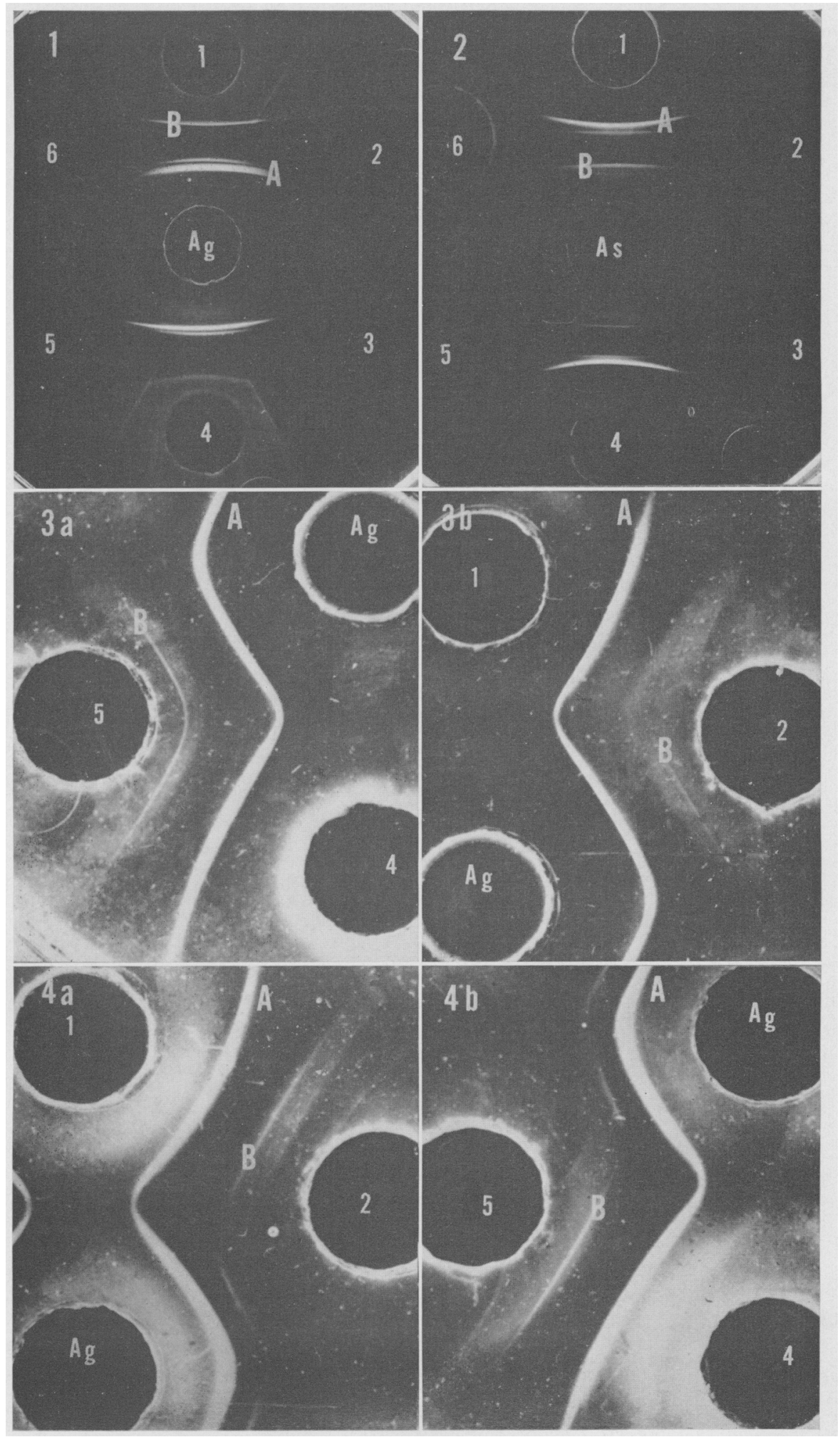


PI..11'1: 2

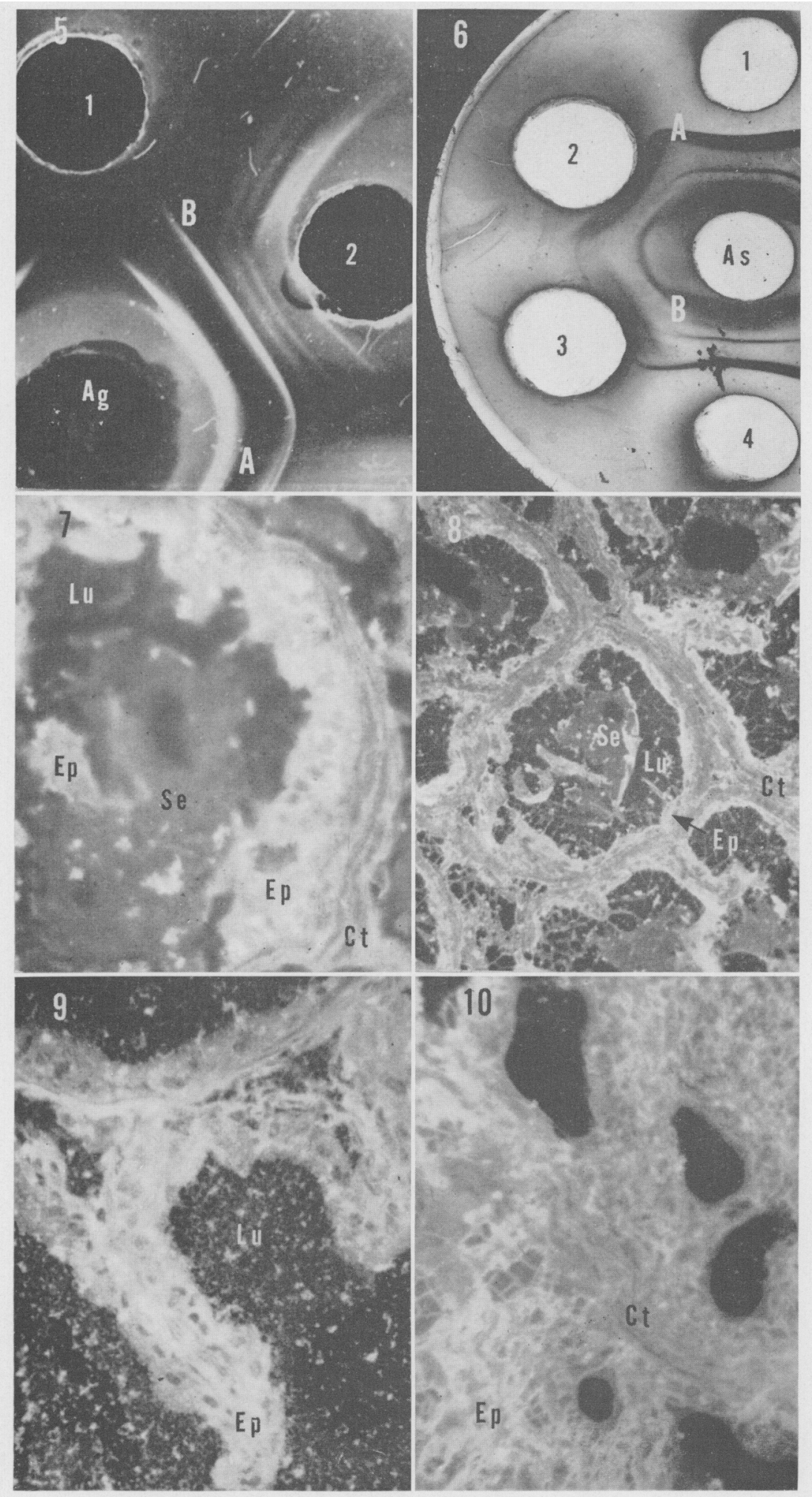


PLATF, 3

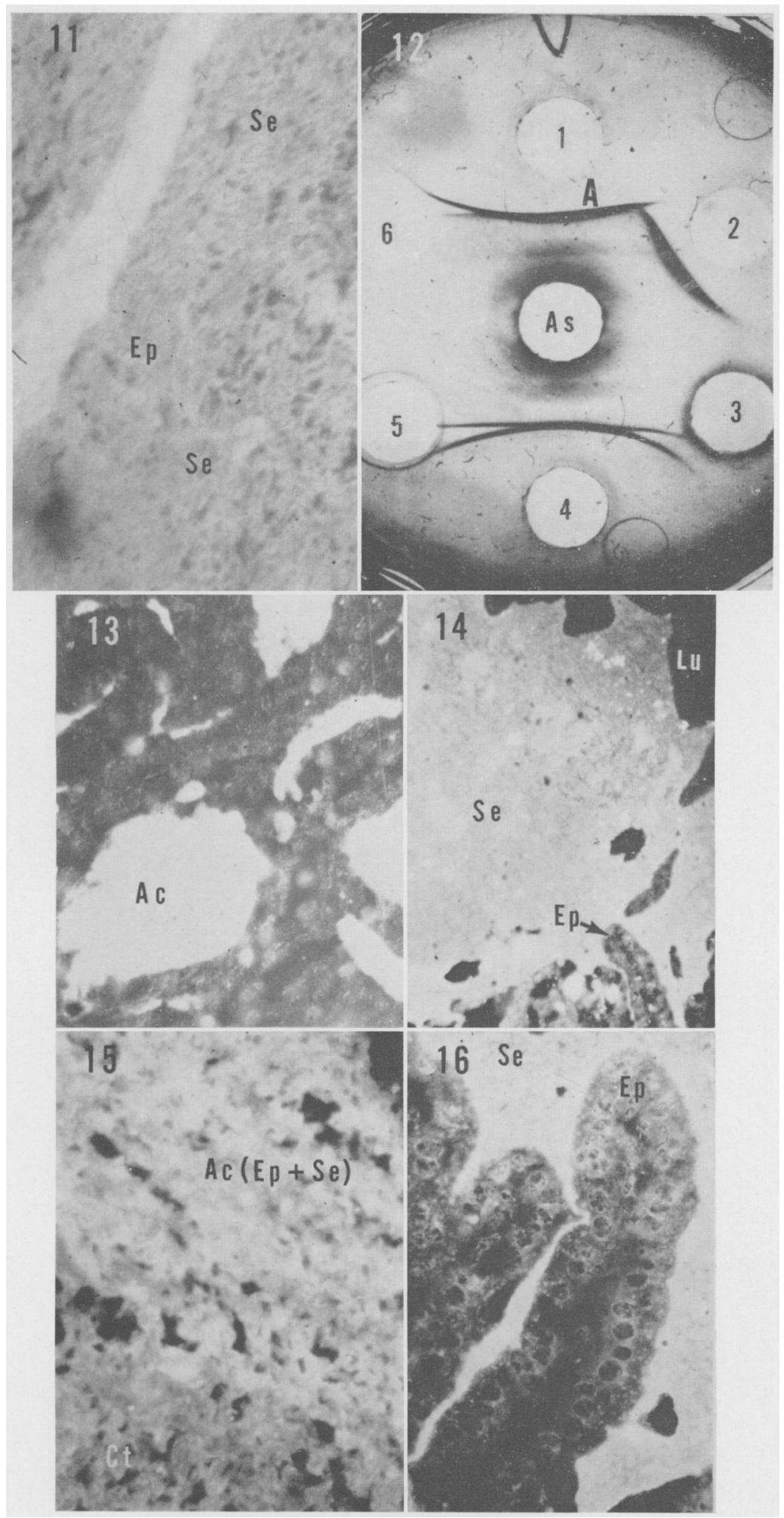


Figs. 13 to 16. Reaction of fluorescein-labelled anti-rat complex serum (absorbed with lyophilized normal rat serum and washed sediment of human liver) with mouse accessory glands. Ac $=$ acinus, $\mathrm{Ct}=$ connective tissue, $\mathrm{Ep}=$ epithelial cells, $\mathrm{Lu}=$ lumen, $\mathrm{Se}=$ secretion. Fig. 13: Seminal vesicle (acinus), $\times 100$. Fig. 14: Seminal vesicle (lumen), $\times 100$. Fig. 15: Dorsolateral prostate. Note the intermixture of cords of epithelial cells and secretion. $\times 100$. Fig. 16 : Coagulating gland, $\times 250$. 